\title{
Nutrient utilization and rumen metabolism in sheep fed Prosopis juliflora pods and Cenchrus grass
}

\author{
Om Hari Chaturvedi and Artabandhu Sahoo*
}

\begin{abstract}
The present study was conducted to evaluate the effect of replacement of Prosopis juliflora pods (PJP) in the concentrate mixture fed to sheep along with Cenchrus grass (CG). Twenty four adult Malpura rams (3-5 years, $45.4 \pm 4.26 \mathrm{~kg}$ ) were randomly divided into three equal groups on the basis of age and live weight (LW). Mature green Prosopis juliflora pods were collected, dried and ground to replace concentrate mixture at 0 (G1), 30\% (G2) or $40 \%$ (G3). Cenchrus grass was offered ad libitum whereas the concentrate mixture was fed at the rate of $1 \% \mathrm{LW}$. Nutrient digestibility did not differ among the groups while $\mathrm{N}$ balance data showed reduced utilization in G3. However, the animals in G1, G2 and G3 maintained LW and their nutritional profile indicated surplus of energy and protein with comparable feed value of all the three diets. Rumen $\mathrm{pH}$ decreased and volatile fatty acids increased ( $P<0.05) 4 \mathrm{~h}$ after feeding in G2 and G3 compared to G1. In summary, Prosopis juliflora pods can replace concentrate mixture up to $40 \%$ in sheep feeding without any adverse effect on nutrient intake and utilization as well as rumen fermentation characteristics.
\end{abstract}

Keywords: Prosopis juliflora pods; Cenchrus grass; Nutrient utilization; Rumen metabolism; Sheep

\section{Introduction}

In many countries including India, sheep are raised on rangeland and stubble grazing. Fodder trees and bushes known as top feeds often become part of the diet during scarcity (lean) season to make up the scarce vegetation to meet with nutritional requirements (Rangnekar 2002). The rangelands of the semi-arid regions of India are covered with a wide variety of vegetation mainly grasses, bushes, shrubs and trees and the biomass yield of the community rangelands is generally low due to high stocking density and overgrazing (Sankhyan et al. 1999). Therefore, sheep grazing on such land are underfed for most part of the year. Further, a majority of the sheep farmers in this region do not supplement concentrate even in critical physiological stages thereby undermining average production from sheep (Chaturvedi et al. 2008). In most of the tropical countries, the rangeland area is gradually shrinking that adds to stocking pressure and low productivity. Consequently, in this scenario of feed

\footnotetext{
* Correspondence: sahooarta1@gmail.com

Division of Animal Nutrition, Central Sheep and Wool Research Institute, Avikanagar, Rajasthan 304 501, India
}

resource crunch, expanding use of alternate feeds and fodder seems to be one of the viable approaches.

Prosopis juliflora Swartz (family Leguminosae, subfamily Mimosoideae) is a perennial, fast-growing, often ever-green and drought resistant shrub or tree that grows in semi-arid areas all over the world and is commonly known as Vilayati babool in India. It has also been planted successfully under desert like conditions where it is often used to halt shifting sand dune encroachment. A high yield (169 kg/tree/year) with production output estimated over two million tonnes in India (Sawal et al. 2004), P. juliflora pods (PJP) promises to be an alternate feed resource that can be used by feed processing industries for livestock. Usefulness of PJP in livestock feeding has been reported earlier (Sawal et al. 2004; Singh et al. 2004; Pandya et al. 2005; Sharma et al. 2006). In this line, Abdullah and Abdel Hafes (2004) reported comparable crude protein and energy contents of PJP to barley grain. Further, these pods contain good amount of protein and energy with $20 \%$ soluble sugars and hence are sweet in taste and increase palatability of feed (Talpada et al. 2003). Talpada et al. (2002) also reported successful inclusion of 
PJP at 30\% level in compounded cattle feed without any adverse effect on feed intake, digestibility, rumen fermentation. However, the information on feeding of PJP in place of concentrate mixture is scanty in sheep feeding practice. The present study was, therefore, undertaken to evaluate the effect of feeding PJP in replacement of concentrate mixture along with Cenchrus grass (CG) on nutrient utilization and rumen fermentation characteristics in sheep.

\section{Materials and methods}

\section{Animals and housing}

The experimental animals were housed in a well-ventilated enclosure with facility for individual feeding and watering. Animal care, handling and sampling procedures were approved by Institute's Animal Ethics Committee.

\section{Feeds and feeding}

Twenty four adult Malpura rams (3-5 years, 45.4 \pm $4.26 \mathrm{~kg}$ ) were divided randomly into 3 equal groups ( $\mathrm{n}=8$ ) of diets: 0 (G1), 30 (G2) and 40\% (G3) Prosopis juliflora pods (PJP) in replacement of the concentrate mixture. The composition of the concentrate mixture was $67,30,2.0,0.95$ and $0.05 \%$ of barley, groundnut cake (solvent extracted), mineral mixture, common salt and vitamin supplements, respectively. The PJP was collected, sun dried, ground and then included in the concentrate. The concentrate was fed at $1 \%$ live weight while the CG was offered ad libitum at 09:00 h. Ad libitum clean drinking water was made available to all the animals. The feeds offered and the residues left were recorded daily.

\section{Metabolism trial}

A metabolism trial was conducted after $30 \mathrm{~d}$ of experimental feeding and the study lasted for $10 \mathrm{~d}$ (i.e. $4 \mathrm{~d}$ adaptation in metabolism cages $\left(5.5^{\prime} \times 2.0^{\prime}\right)$ followed by 6 $\mathrm{d}$ of sample collection). Daily feed intake and output of faeces and urine was recorded and representative samples were collected for further processing. Faeces and urine were collected using a total collection method in which urine was collected into containers with toluene as preservative. Fractional aliquot of feed, faeces and urine samples were brought to laboratory for further processing. The dry matter (DM) of feed, faeces and residue was determined by drying to a constant weight in a forced air oven (NSW-143, Narang Scientific Works Ltd., New Delhi) at $70^{\circ} \mathrm{C}$. The dried samples of each day collections were pooled for $6 \mathrm{~d}$, ground to pass a $1 \mathrm{~mm}$ screen and preserved for chemical analysis. For $\mathrm{N}$ estimation, aliquot of faeces $(0.1 \%)$ and urine (1\%) from the individual animals were collected every morning and pooled in a $500 \mathrm{ml}$ Kjeldahl flask containing $25 \mathrm{ml}$ of concentrated sulphuric acid.

\section{Nutrient and nutritive value assay}

Samples of feeds, residue and faeces were analysed for ash and crude protein $(\mathrm{CP})$ according to procedure of AOAC (1995). Neutral detergent fibre (NDF), acid detergent fibre (ADF), acid detergent lignin (ADL) analysed as per Van Soest et al. (1991). Organic matter (OM), cellulose and hemicelluloses contents were calculated by difference (i.e., by subtracting ash from DM, ADL from $\mathrm{ADF}$ and $\mathrm{ADF}$ from NDF, respectively).

The nutritive value of feed was assessed from metabolizable energy (ME) and relative feed value (RFV) of feed in different dietary groups by applying the following equations:

$$
\begin{aligned}
\mathrm{ME} \text { intake }(\mathrm{MJ} / \mathrm{kg} \mathrm{DM})= & {[(\text { digestible OM, g/ } \mathrm{kg} \mathrm{DM}) / 1000] } \\
& \times 18.5 \times 0.81 ;
\end{aligned}
$$

(ARC 1990).

$\mathrm{RFV}=\{$ Digestible DM $(\%) \times \mathrm{DM}$ intake $(\%$ of $\mathrm{LW})\} / 1.29 ;$

(Jeranyama and Garcia 2004).

\section{Ruminal attributes}

Rumen liquor $(50 \mathrm{ml})$ was collected from each intact rams at 0,4 and $8 \mathrm{~h}$ of post feeding using a stomach tube consecutively for two days. Each sample was placed in a $100 \mathrm{ml}$ glass jar and recorded $\mathrm{pH}$ using a portable calibrated digital $\mathrm{pH}$ meter (Model PH5652A, Electronic Corporation of India Ltd) within 4-5 min of sampling. Rumen fluid was strained through a four layers of muslin cloth, pooled over two days and stored at $-20^{\circ} \mathrm{C}$ for further analysis, i.e., total $\mathrm{N}$ (AOAC 1995) and total volatile fatty acids (VFA) (Barnett and Reid 1957).

\section{Statistical analysis}

The statistical software SPSS version 16.0 (SPSS Inc. Chicago, IL 60606-6307, USA) was used for the analysis of data. Two-way analysis of variance was employed for analyzing the data on rumen parameters to see the effect of treatments, periods and their interactions. Polynomial contrast was applied to assess the effect of levels of supplementation and the significance amongst the means was tested by applying Duncan's Multiple Range Test and significance was declared at $\mathrm{P}<0.05$.

\section{Results}

Nutrient composition, intake and digestibility

The concentrate mixture had CP $225 \mathrm{~g} / \mathrm{kg}$ DM, while that of PJP was $183 \mathrm{~g} / \mathrm{kg}$ DM, which also had low ash 
and lignin content. Unlike, the CG had low CP and high NDF and ADF contents (Table 1). No animals had residual concentrates that was given at $1 \%$ of their body weight. Above all, there was no differences $(P \geq 0.59)$ in roughage, total feed and nutrient intake between the diets (Table 2). Similarly, the digestibility of nutrients did not differ $(\mathrm{P} \geq 0.30)$ between the diets.

\section{Nitrogen balance}

Similar to $\mathrm{CP}$ intake, $\mathrm{N}$ intake did not differ between the groups (Table 2). A linear decrease $(\mathrm{P}<0.05)$ in $\mathrm{N}$ retention was detected with the increase of PJP in the diet. Similar trend was also observed for $\mathrm{N}$ retention as per cent of intake or absorbed. However, no difference $(\mathrm{P}>0.05)$ was noticed in $\mathrm{N}$ balance between $\mathrm{G} 1$ and $\mathrm{G} 2$ diets.

\section{Ruminal attributes}

There was a decline in $\mathrm{pH}$ in G2 and G3 compared to G1 during both pre- and post-feeding periods (Figure 1). The post-prandial alterations in rumen $\mathrm{pH}$ were also significant within the groups. Total VFA concentration showed periodic fluctuation with higher values in all the groups during $4 \mathrm{~h}$ post-feeding that dropped during $8 \mathrm{~h}$ to comparable values as it was during pre-feeding (Figure 2). No difference was observed in total VFA concentration between the groups, but the values at $4 \mathrm{~h}$ post-feeding was significantly higher in PJP fed groups. The total $\mathrm{N}$ concentration showed a similar trend (Figure 3) as it was for total VFA in different dietary groups as well as during post-feeding hours.

\section{Nutritive value of diets and nutritional profile of sheep}

There was comparable digestible $\mathrm{OM}$ and ME content of total diets that were being fed to animals under

Table 1 Chemical composition (g/kg DM) of feedstuffs fed to rams

\begin{tabular}{lccc}
\hline Attributes & $\begin{array}{c}\text { Concentrate } \\
\text { mixture* }\end{array}$ & $\begin{array}{c}\text { Prosopis } \\
\text { juliflora pods }\end{array}$ & $\begin{array}{c}\text { Cenchrus } \\
\text { grass }\end{array}$ \\
\hline Ash & 117 & 78.0 & 110 \\
Organic matter & 883 & 922 & 890 \\
Crude protein & 225 & 183 & 85.3 \\
Neutral detergent fiber & 291 & 391 & 717 \\
Acid detergent fiber & 133 & 276 & 442 \\
Acid detergent lignin & 35.8 & 61.6 & 66.6 \\
Hemicellulose & 158 & 115 & 276 \\
Cellulose & 97.0 & 215 & 375 \\
\hline
\end{tabular}

${ }^{*}$ Concentrate mixture (\% composition): barley 67 , groundnut cake (solvent extracted) 30, mineral mixture (calcium 320, phosphorus 62, Manganese 2.7, zinc 2.6, iron 1.0, fluorine 0.9 , iodine 0.1 , copper $0.1 \mathrm{~g} / \mathrm{kg}$ ) 2 , common salt 0.95 and vitamin supplements (Vitamin A 100000 I.U, Vitamin D 20000 I.U per $100 \mathrm{~g}) 0.05$. different groups except that the $\mathrm{CP}$ and DCP content declined linearly in G2 and G3 compared to G1 (Table 3). However, the DM, OM and ME intake per unit LW did not differ between the groups. Inclusion of PJP in the diet did not have any significant $(\mathrm{P}>0.05)$ effect on alteration in LW during this study.

\section{Discussion}

The nutrient composition of CG was in close agreement to earlier reports (Mishra et al. 1997; Shinde et al. 1997). With $18.34 \%$ CP, PJP can be grouped in protein-rich concentrates and the findings corroborated with earlier reports (Sawal et al. 2004; Mahgoub et al. 2005). Further, concentrates replaced by PJP at 30 and $40 \%$ showed comparable acceptability as evidenced from feed intake in different groups. A non-significant difference in digestibility of nutrients between the groups corroborate to this level of PJP inclusion as an alternate feed resource. Rao and Reddy (1983) found similar effect on feed intake in cattle fed concentrate mixtures containing $40 \%$ PJP and so was the observation up to $20 \%$ of the diet by Talpada et al. (2002). On the basis of total feed intake, the proportion of PJP in the total diets was only 9 and 12\%, which was considerably less than these reported inclusion levels and thus the diets were readily accepted by sheep and there was comparable DM intake in the three dietary groups.

A similar intake and digestibility of nutrients between the groups contributed to comparable digestible $\mathrm{OM}$ and ME contents in the three diets. But, a reduced level of CP and DCP content of diet in G2 and G3 was attributable to relatively lower CP in PJP compared to concentrate mixture (Table 1) when replaced at 30 and $40 \%$ level. Contrast to the findings in the present experiment, a great degree of variability was noted in digestibility of PJP (Sawal et al., 2004) and it may be attributed to variability in topography and season of collection (Chopra and Hooda 2001). Reports on the composition and nutritive value of PJP showed that they are a potential source of protein and energy, although pod composition varies with location. The RFV of feeds calculated from actual values (in place of predicted values) could be an indicator to compare the three diets, and a value of 150 may thus be considered to support animals above its maintenance requirement if intake is not limited for production output. This can be further substantiated by assessing the intake of CP, DCP and ME per $\mathrm{kg} \mathrm{W}^{0.75}$ in different groups, which showed that all the three diets could very well support production due to additional $30 \% \mathrm{ME}$ available from the respective diets over and above the maintenance need (NRC 2007). The level of $\mathrm{CP} / \mathrm{DCP}$ in the three diets was $50 \%$ higher and could thus very well support requirement of growing animals or the extra amount can be excluded to reduce the feed 
Table 2 Nutrient intake, digestibility, nitrogen balance and ruminal attributes of sheep on different diets

\begin{tabular}{|c|c|c|c|c|c|c|c|}
\hline \multirow[t]{2}{*}{ Parameters } & \multirow[t]{2}{*}{ G1 } & \multirow[t]{2}{*}{ G2 } & \multirow[t]{2}{*}{ G3 } & \multirow[t]{2}{*}{ SEM } & \multirow[t]{2}{*}{ 'P' value } & \multicolumn{2}{|c|}{ Significance } \\
\hline & & & & & & Linear & Quadratic \\
\hline \multicolumn{8}{|l|}{ Feed and nutrient intake $(\mathrm{g} / \mathrm{d})$} \\
\hline Roughage DM (g/d) & 1026 & 1026 & 1061 & 34.3 & 0.721 & 0.486 & 0.699 \\
\hline Concentrate DM (g/d) & 408 & 419 & 434 & 14.2 & 0.456 & 0.222 & 0.898 \\
\hline Total DM (g/d) & 1434 & 1445 & 1495 & 43.6 & 0.591 & 0.343 & 0.729 \\
\hline Roughage \% in diet & 71.5 & 71.0 & 70.9 & 0.66 & 0.822 & 0.561 & 0.843 \\
\hline Organic matter & 1286 & 1297 & 1342 & 39.0 & 0.575 & 0.328 & 0.735 \\
\hline Crude protein & 179 & 173 & 175 & 51.6 & 0.658 & 0.551 & 0.497 \\
\hline Neutral detergent fibre & 854 & 875 & 912 & 27.3 & 0.349 & 0.160 & 0.818 \\
\hline Acid detergent fibre & 507 & 524 & 564 & 16.4 & 0.079 & 0.031 & 0.563 \\
\hline Hemicellulose & 347 & 352 & 348 & 10.9 & 0.952 & 0.952 & 0.763 \\
\hline Cellulose & 424 & 440 & 460 & 13.8 & 0.223 & 0.090 & 0.913 \\
\hline Metabolizable energy (MJ) & 11.24 & 11.56 & 12.01 & 0.450 & 0.493 & 0.246 & 0.908 \\
\hline \multicolumn{8}{|l|}{ Digestibility (g/kg) } \\
\hline Dry matter & 561 & 570 & 572 & 16.7 & 0.896 & 0.664 & 0.883 \\
\hline Organic matter & 562 & 571 & 575 & 16.4 & 0.832 & 0.563 & 0.889 \\
\hline Crude protein & 804 & 813 & 804 & 12.2 & 0.845 & 0.980 & 0.570 \\
\hline Neutral detergent fibre & 461 & 482 & 495 & 21.7 & 0.556 & 0.294 & 0.867 \\
\hline Acid detergent fibre & 452 & 475 & 499 & 20.6 & 0.304 & 0.131 & 0.997 \\
\hline Hemicellulose & 561 & 560 & 590 & 19.4 & 0.486 & 0.313 & 0.527 \\
\hline Cellulose & 506 & 534 & 525 & 19.2 & 0.696 & 0.578 & 0.529 \\
\hline \multicolumn{8}{|l|}{ Nitrogen $(N)$ balance } \\
\hline$N$ intake $(g / d)$ & 28.72 & 27.65 & 28.00 & 0.825 & 0.658 & 0.551 & 0.497 \\
\hline Faecal N (g/d) & 5.64 & 5.18 & 5.49 & 0.389 & 0.707 & 0.790 & 0.439 \\
\hline Urinary N (g/d) & 8.27 & 8.26 & 9.86 & 0.543 & 0.097 & 0.062 & 0.249 \\
\hline$N$ retained $(\mathrm{g} / \mathrm{d})$ & 14.81 & 14.21 & 12.66 & 0.645 & 0.090 & 0.036 & 0.556 \\
\hline$N$ retained $\%$ of intake & $51.4^{b}$ & $51.5^{\mathrm{b}}$ & $45.2^{\mathrm{a}}$ & 1.70 & 0.033 & 0.023 & 0.148 \\
\hline $\mathrm{N}$ retained $\%$ of absorbed & $64.0^{\mathrm{b}}$ & $63.4^{\mathrm{b}}$ & $56.2^{a}$ & 2.00 & 0.031 & 0.017 & 0.207 \\
\hline \multicolumn{8}{|l|}{ Ruminal attributes } \\
\hline $\mathrm{pH}$ & 6.34 & 6.31 & 6.23 & 0.061 & 0.085 & 0.190 & 0.767 \\
\hline Total volatile fatty acids (mM/L) & 95.0 & 100.8 & 99.2 & 6.05 & 0.487 & 0.621 & 0.615 \\
\hline Total N (g/L) & 2.68 & 2.90 & 2.96 & 0.019 & 0.202 & 0.149 & 0.635 \\
\hline
\end{tabular}

Means bearing different superscripts in a row differ significantly $(P<0.05)$.

G1 (Control), Concentrate + Cenchrus; G2, Concentrate with 30\% P. juliflora pods + Cenchrus; G3, Concentrate with $40 \%$ P. juliflora pods + Cenchrus.

cost of diet in the feeding of sheep. The $\mathrm{N}$ balance data that showed a decline in $\mathrm{N}$ utilization $(\mathrm{N}$ retained, $\mathrm{N}$ retained as percent of intake and absorbed) at $40 \%$ level of PJP inclusion could be attributed to relatively higher $(\mathrm{P}=0.097)$ urinary excretion of $\mathrm{N}$. Moreover, a significant amount of $\mathrm{N}$ retention that was not reflected with additional LW gain in mature Malpura sheep can be harnessed for growth and production in desired animals.

The effect replacing concentrate mixture with PJP on ruminal $\mathrm{pH}$, total VFA $(\mathrm{mM} / \mathrm{L})$ and total $\mathrm{N}(\mathrm{g} / \mathrm{L})$ was assessed to take note of change in ruminal environment.
A reduction in $\mathrm{pH}$ and increase in total VFA at $4 \mathrm{~h}$ postfeeding in G2 and G3 compared to G1 may be attributed to presence of fermentable carbohydrates in PJP. It has been reported that PJP is rich in saccharose (20-25\% of DM) and reduced sugar (10-20\% of DM) (Silva 1986). Further, a corresponding increase in total N could be correlated to higher concentration of soluble $\mathrm{N}$ in PJP and this might have contributed to higher urinary output. Moreover, PJP with ready supply of fermentable carbohydrate in the rumen might have improved utilization of ammonia by microbes and ensured better supply of protein and energy for production. The present 


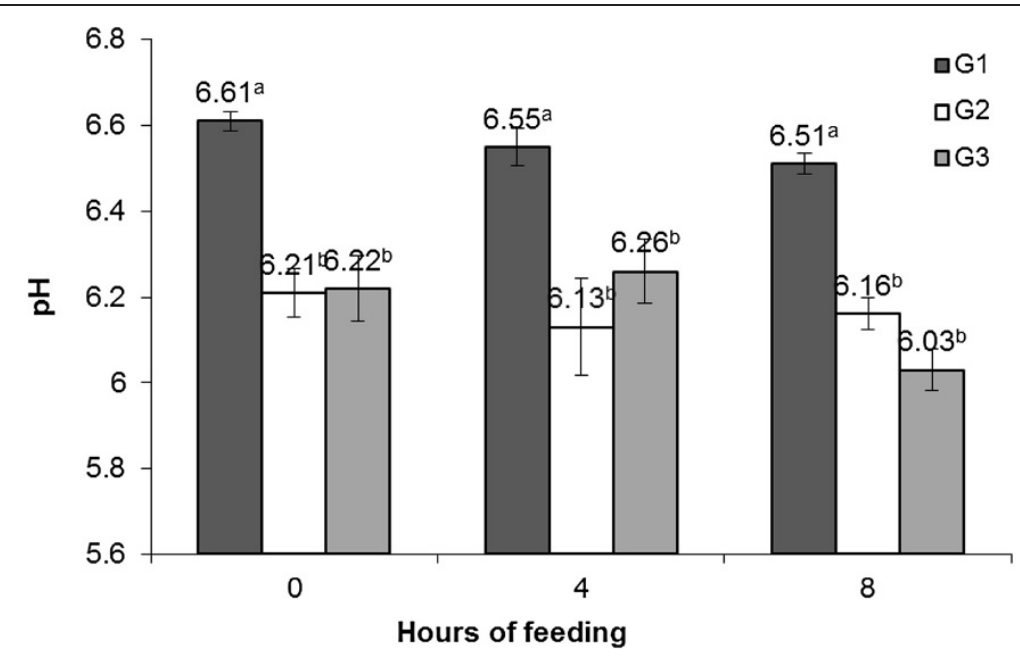

Figure 1 Diurnal changes in rumen $\mathrm{pH}$ during post-feeding hours in different groups.

findings on rumen fermentation are in close agreement to those reported earlier (Ravikala et al. 1993; Talpada et al. 2002; Sharma et al. 2007).

On the basis of this study on intake and digestibility of nutrients, rumen fermentation attributes and nutritional profile of Malpura sheep, it may be suggested that complete rations using non conventional feed ingredients could be successfully made and tried in the diet of sheep to bridge the gap between demand and supply and to get maximum economic production. Feed costs were reduced by $26 \%$ when PJP replaced up to $50 \%$ of the concentrate diet of sheep, without affecting their growth (Sawal et al. 2004). The local price of PJP is observed to be $25 \%$ of the price of concentrate mixture and thus at $40 \%$ level of replacement the price would be reduced by $30 \%$. In a series of experiments, Talpada et al. (2002) also found suitability of incorporating PJP in the complete diet of crossbred calves. Thus, PJP that is available at ease with the farmers of semi-arid/arid tropics could very well substitute cereal grains and oil cakes in the concentrate mixture. This would encourage the incorporation of unutilized or underutilized feeds and thereby harnessing and optimizing maximum benefit from the available natural resources for sustainability.

\section{Conclusion}

It is concluded that Prosopis juliflora pods can replace concentrate mixture up to $40 \%$ in sheep feeding without having any adverse effect on nutrient intake and utilization as well as on ruminal attributes. Thus, PJP that is available at ease with the farmers of semi-arid/ arid tropics could very well substitute cereal grains and oil cakes in the concentrate mixture and may thus provide opportunity to economize the ration for sheep while sparing these ingredients for poultry and other livestock or food for human consumption.

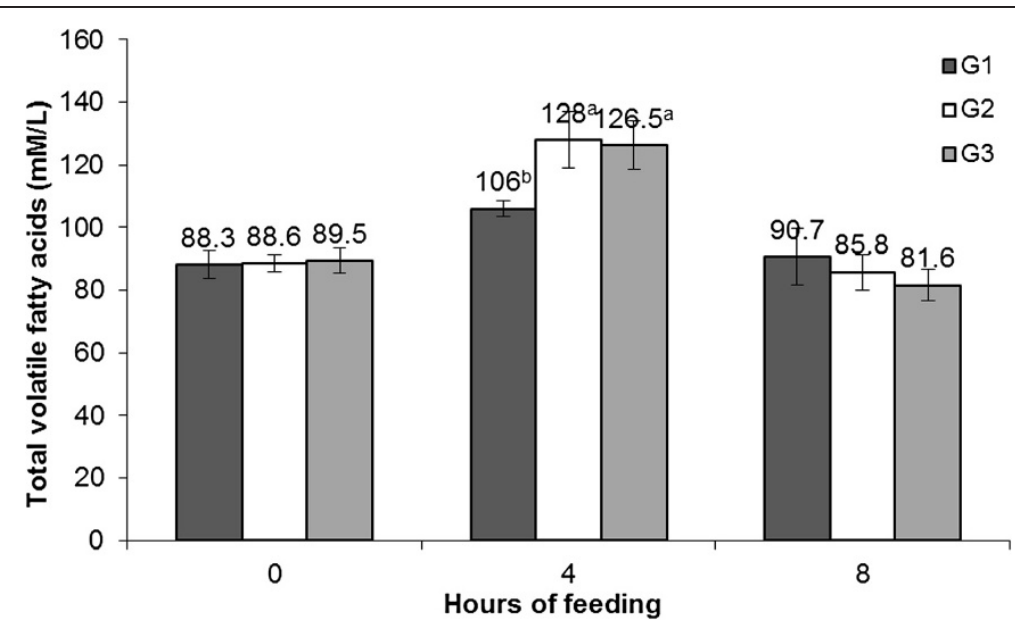

Figure 2 Diurnal changes in rumen volatile fatty acids (mM/L) during post-feeding hours in different groups. 


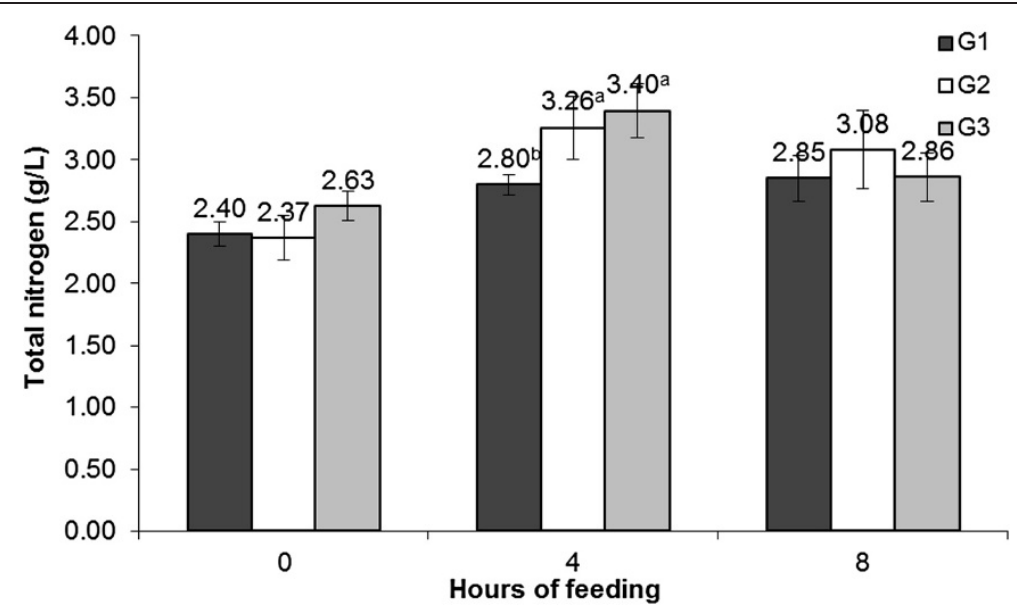

Figure 3 Diurnal changes in rumen total $\mathrm{N}$ during post-feeding hours in different groups.

Table 3 Nutritive value of diets and nutritional profile of sheep in different groups

\begin{tabular}{|c|c|c|c|c|c|c|c|}
\hline \multirow[t]{2}{*}{ Parameters } & \multirow[t]{2}{*}{ G1 } & \multirow[t]{2}{*}{ G2 } & \multirow[t]{2}{*}{ G3 } & \multirow[t]{2}{*}{ SEM } & \multirow[t]{2}{*}{ ‘ $P$ ' value } & \multicolumn{2}{|c|}{ Significance } \\
\hline & & & & & & Linear & Quadratic \\
\hline \multicolumn{8}{|l|}{ Nutritive value } \\
\hline Digestible organic matter (g/kg) & 504 & 513 & 517 & 14.7 & 0.209 & 0.395 & 0.023 \\
\hline Crude protein (g/kg) & $125.2^{b}$ & $119.5^{\mathrm{ab}}$ & $117.1^{\mathrm{a}}$ & 0.79 & $<0.001$ & $<0.001$ & 0.116 \\
\hline Digestible crude protein (g/kg) & $100.6^{b}$ & $97.2^{\mathrm{ab}}$ & $94.2^{\mathrm{a}}$ & 1.50 & 0.033 & 0.010 & 0.894 \\
\hline Metabolizable energy (MJ/kg) & 7.85 & 7.99 & 8.05 & 0.229 & 0.814 & 0.542 & 0.882 \\
\hline Relative feed value* & 149 & 150 & 147 & 5.1 & 0.904 & 0.752 & 0.758 \\
\hline \multicolumn{8}{|l|}{ Nutrient intake (g/kg LW) } \\
\hline Dry matter & 34.2 & 34.0 & 33.2 & 0.70 & 0.561 & 0.311 & 0.757 \\
\hline Digestible organic matter & 17.3 & 17.4 & 17.1 & 0.58 & 0.932 & 0.860 & 0.748 \\
\hline Crude protein & $4.28^{\mathrm{b}}$ & $3.95^{\mathrm{a}}$ & $3.88^{\mathrm{a}}$ & 0.059 & 0.002 & $<0.001$ & 0.740 \\
\hline Digestible crude protein & $3.45^{\mathrm{b}}$ & $3.20^{\mathrm{ab}}$ & $3.12^{\mathrm{a}}$ & 0.072 & 0.026 & 0.008 & 0.873 \\
\hline Metabolizable energy (J) & 269 & 271 & 267 & 9.1 & 0.932 & 0.860 & 0.748 \\
\hline \multicolumn{8}{|l|}{ Nutrient intake $\left(\mathrm{g} / \mathrm{kgW}^{0.75}\right)$} \\
\hline Dry matter & 87.0 & 86.7 & 86.0 & 1.62 & 0.890 & 0.643 & 0.920 \\
\hline Digestible organic matter & 43.9 & 44.5 & 44.3 & 1.43 & 0.853 & 0.825 & 0.834 \\
\hline Crude protein & $10.90^{b}$ & $10.36^{a}$ & $10.06^{\mathrm{a}}$ & 0.139 & 0.004 & 0.001 & 0.508 \\
\hline Digestible crude protein & 8.76 & 8.42 & 8.09 & 0.174 & 0.055 & 0.018 & 0.980 \\
\hline Metabolizable energy (J) & 684 & 693 & 691 & 22.9 & 0.953 & 0.825 & 0.834 \\
\hline \multicolumn{8}{|l|}{ Live weight change } \\
\hline Initial live weight (kg) & 45.3 & 45.2 & 45.8 & 1.57 & 0.963 & 0.842 & 0.853 \\
\hline Final live weight (kg) & 45.5 & 46.2 & 46.5 & 1.59 & 0.895 & 0.646 & 0.939 \\
\hline Gain (kg) & 0.18 & 0.99 & 0.78 & 0.430 & 0.399 & 0.335 & 0.342 \\
\hline
\end{tabular}

ME intake $(\mathrm{MJ} / \mathrm{kg} \mathrm{DM})=[($ digestible OM, $\mathrm{g} / \mathrm{kg} \mathrm{DM}) / 1000] \times 18.5 \times 0.81 ;\{$ ARC, 1990$\}$.

* Relative feed value $(\mathrm{RFV})=\{$ Digestible dry matter $(\%) \times$ Dry matter intake $(\%$ of live weight $)\} / 1.29 ;\{$ Jeranyama and Garcia, 2004$\}$.

Means bearing different superscripts in a row differ significantly $(P<0.05)$.

G1 (Control), Concentrate + Cenchrus; G2, Concentrate with 30\% P. juliflora pods + Cenchrus; G3, Concentrate with 40\% P. juliflora pods + Cenchrus. 


\section{Competing interests}

Both authors declare that they have no competing interests.

\section{Authors' contributions}

$\mathrm{OHC}$ : Collected the feed materials, carried out the in vivo experimentation and drafted the manuscript. AS: Formulated the ration, carried out rumen profile, data interpretation and analysis, final drafting of the manuscript. Both authors read and approved the final manuscript.

\section{Acknowledgement}

We thank the Director, Central Sheep and Wool Research Institute, Avikanagar for providing necessary facilities while undertaking the research programme.

Received: 30 May 2013 Accepted: 7 November 2013

Published: 9 November 2013

\section{References}

Abdullah AY, Abdel Hafes BY (2004) Inclusion of Prosopis juliflora pods in finishing Awassi lamb diets. Proceedings of the 11th AAAP Animal Science Congress, vol. 2., pp 373-375

AOAC (1995) Official Methods of Analysis, 16th edn. Association of Official Analytical Chemists, Washington, DC

ARC (1990) The nutrient requirement of ruminant livestock. Supplement 1. Agricultural Research Council, Commonwealth Agricultural Bureaux, Farham Royal, UK, pp 78-80

Barnett AJG, Reid RL (1957) Studies on the production of volatile fatty acids from grass by rumen liquor in an artificial rumen. I. The volatile fatty acid production of fresh grass. J Agric Sci 48:315-321

Chaturvedi OH, Sankhyan SK, Mann JS, Karim SA (2008) Livestock holding pattern and feeding practices in semiarid eastern region of Rajasthan. Indian J Small Rumin 14:224-229

Chopra D, Hooda MS (2001) Variability in chemical composition of Prosopis juliflora seeds and hull. Indian J Anim Nutr 18:282-284

Jeranyama P, Garcia AD (2004) Understanding relative feed value (RFV) and relative forage quality (RFQ). ExEx8149, August 2004., [http://pubstorage. sdstate.edu/AgBio_Publications/articles/ExEx8149.pdf]

Mahgoub O, Kadim IT, Forsberg NE, Dawood S, Al-Ajmi Al-Saqry NM, Al-Abri AS, Annamalai K (2005) Evaluation of Meskit (Prosopis juliflora) pods as a feed for goats. Anim Feed Sci Technol 121:319-327

Mishra AS, Santra A, Chaturvedi OK, Prasad R, Karim SA (1997) Comparative nutrient utilisation in sheep and goats on cenchrus (Cenchrus ciliaris) based diet. Indian J Anim Nutr 14:250-253

NRC (2007) Nutrient Requirements of Small Ruminants. National Research Council, US National Academy of Science, Washington DC

Pandya PR, Patel GR, Gupta RS, Patel DC, Pande MB, Desai MC (2005) Effect of Wheat straw based total mixed ration with Prosopis juliflora pods (Mesquite pods) on performance of lactating cows. Inte J Cow Sci 1:66-72

Rangnekar DV (2002) Feeding systems based on the traditional use of trees for feeding livestock. In: Speedy A, Pugliese PL (eds) Legume trees and other fodder trees as protein sources for livestock. FAO Animal Production and Health Paper 102, Rome, pp 221-231, Proceedings of the FAO Expert Consultation Malaysian Agricultural Research and Development Institute (MARDI), Kuala Lumpur, Malaysia, 14-18 October 1991

Rao NSR, Reddy MS (1983) Utilization of Prosopis juliflora pods in the concentrate feed of cattle and sheep. Indian J Anim Sci 53:367-372

Ravikala K, Patel AM, Murty KS, Desai MC (1993) Rumen metabolites in growing lambs on feeding Prosopis juliflora based complete feeds. Indian J Anim Nutr 10:177-180

Sankhyan SK, Shinde AK, Karim SA (1999) Seasonal changes in biomass yield, nutrient intake and its utilization by sheep maintained on public rangeland. Indian J Anim Sci 69:617-620

Sawal RK, Ratan R, Yadav SBS (2004) Mesquite (Prosopis juliflora) Pods as a Feed Resource for Livestock- A Review. Asian Australas J Anim Sci 17:719-725

Sharma V, Purohit GR, Arya RS, Harsh M (2006) Evaluation of some complete rations in sheep incorporating unconventional feed resources of arid zone of India. Anim Nutr Feed Technol 6:135-141

Sharma T, Dhuria RK, Mathur BK, Arya RS, Singh AP, Purohit GR (2007) Effect of inclusion of mesquite (Prosopis juliflora) pods and urea supplementation in concentrate ration of sheep on nitrogen degradability. Vet Pract 8:98-104
Shinde AK, Karim SA, Patnayak BC, Mann JS (1997) Dietary preference and grazing behaviour of sheep on Cenchrus ciliaris pasture in a semi-arid region of India. Small Rumin Res 26:119-122

Silva S (1986) Prosopis juliflora (SW) DC in Brazil. The current state of knowledge on Prosopis juliflora. II International Conference on Propopis recife, 25-29 Aug, 1986 at Brazil. FAO, Rome, pp 29-51

Singh NP, Sankhyan SK, Shinde AK (2004) Animal Nutrition and Feed Resource Development Research. Central Sheep and Wool Research Institute, Avikanagar, India, pp 4-6

Talpada PM, Pandya PR, Patel GR, Patel DC, Desai MC (2002) Utilization of complete feds using Prosopis juliflora pods as a ration of growing crossbred calves. Indian J Anim Nutr 19:1-6

Talpada PM, Pandya PR, Pande MB (2003) Technical Bulletin on Unconventional feed resources for livestock. Animal Nutrition Research Department, Anand Agricultural University, Anand, India

Van Soest PJ, Robertson JB, Lewis BA (1991) Methods for dietary fibre, neutral detergent fibre and non starch polysaccharides in relation to animal nutrition. J Dairy Sci 74:3583-3597

doi:10.1186/2193-1801-2-598

Cite this article as: Chaturvedi and Sahoo: Nutrient utilization and rumen metabolism in sheep fed Prosopis juliflora pods and Cenchrus grass. SpringerPlus 2013 2:598.

\section{Submit your manuscript to a SpringerOpen ${ }^{\circ}$ journal and benefit from:}

- Convenient online submission

- Rigorous peer review

- Immediate publication on acceptance

- Open access: articles freely available online

- High visibility within the field

- Retaining the copyright to your article

Submit your next manuscript at $>$ springeropen.com 